\title{
The Pillboxes of Lanzarote (Spain)
}

\author{
Giancarlo T. Tomezzoli \\ Etno-Archaeological Observatory, Munich, Germany \\ Email: gt21949@gmx.de
}

How to cite this paper: Tomezzoli, G. T. (2019). The Pillboxes of Lanzarote (Spain). Archaeological Discovery, 7, 54-74. https://doi.org/10.4236/ad.2019.72004

Received: January 20, 2019

Accepted: February 19, 2019

Published: February 22, 2019

Copyright $\odot 2019$ by author(s) and Scientific Research Publishing Inc. This work is licensed under the Creative Commons Attribution International License (CC BY 4.0).

http://creativecommons.org/licenses/by/4.0/

\begin{abstract}
The visit of Lanzarote took place on November 2018 and allowed to note that its defensive military structures were composed by pillboxes, truncated, pyramidal bases, ground emplacements and artillery bases. This article describes the Playa Blanca and Punta del Papagayo coastal defences and the artillery bases of Mirador del Rio for concluding that today, at about seventy years from the WWII end, they appear in good preservation state and their integrity not particularly menaced by possible further expansions of touristic and residential centres. In addition, their study provided examples of WWII Spanish military architecture and gave hints about the defence concepts involved in the WWII Lanzarote defence.
\end{abstract}

\section{Keywords}

WWII, Canary Islands, Lanzarote, Operation Pilgrim, Coastal Defences, Artillery, Pillbox, Bunkers, Spain

\section{Introduction}

The presence of bunkers in the Canary Islands comes to my attention through an article (Anonym, 2018) dedicated to the Operation Pilgrim. After having reminded the $10^{\text {th }}$ June 1941 meeting between Hitler and the Spanish minister Serrano Suñer dedicated to the possible invasion of Gibraltar (Operation Felix) and summarized the strategic importance of Gibraltar for the British interests, the article introduced the Operation Pilgrim, to be accomplished on September 1941, concerning the British invasion of the Canaries in case of loss of Gibraltar. Suspecting such an invasion Hitler offered anti-aircraft guns and Stukas to be stationed to the islands and the dictator Franco sent concrete to build bunker systems. However, the German Operation Barbarossa and contrasts between Hitler and Franco caused Gibraltar to remain British and no invasion of the Canaries. 


\section{Historical Information}

During the WWII and the years after, the Independent Artillery Group of Canaries (Grupo de Artilleria Independiente de Canarias) was present in the Canaries. It included a $1^{\text {st }}$ artillery section in Tenerife, a $2^{\text {nd }}$ artillery section in Gran Canaria, a Fono-localization group based on Belgian TEPA devices mod. D-20 already used by the Republican Flak during the Spanish Civil War. The $5^{\text {th }}$ Field Group of the Artillery Regiment n. 7 (V Grupo de Campaña del Regimiento de Artilleria n. 7) based on $105 / 22 \mathrm{~mm}$ Vickers guns was present in Tenerife and La Palma. The artillery guns were protected against naval fire and bombardments by casemates resisting up to $200 \mathrm{~kg}$ bombs. On the islands were present machine guns as the $7 \mathrm{~mm}$ Hotchkiss mod. 1914, $8 \mathrm{~mm}$ Fiat mod. 1935, $6.5 \mathrm{~mm}$ Fiat mod. 1914, $8 \mathrm{~mm}$ Saint Etienne mod. 1907 and $7 \mathrm{~mm}$ Colt mod. 1914. Only the first two were suitable for both offensive and defensive actions, the heavier last two were suitable only for static defence. Lacking radars, air exploration and recognition units, the surveillance was based on observatories on the island elevations (Defensa, 2015).

The $12^{\text {th }}$ Coastal Battery of the Artillery Regiment $\mathrm{n} .7$, based on $102 / 45 \mathrm{~mm}$ Ansaldo guns, was in Los Guinchos in Santa Cruz de la Palma. La Palma defence was completed by the $42^{\text {nd }}$ and $131^{\text {st }}$ Infantry battalions, the $231^{\text {st }}$ and $331^{\text {st }} \mathrm{In}$ fantry battalions in case of total mobilisation, an artillery groups based on two 105/22 mm Vickers batteries, two $37 \mathrm{~mm}$ anti-tank guns and two $7.92 \mathrm{~mm}$ Flack guns. The request to Germany of a $150 \mathrm{~mm}$ battery, 5 field batteries, machine guns, projectors, radios and other materials remained unsatisfied. However, La Palma, which due to its orography offered only two possible landing areas, was judged not a defence priority. Much more important were the defence of Tenerife and Gran Canaria at West and Fuerteventura and Lanzarote, with their ports and air fields, at East. An artillery battery with command bunker was built in locality Matas Blancas, Pajara coast (Fuerteventura) (Defensa, 2015).

The allied secret services, formed by personnel members of British enterprises, of the British Las Palmas consulate, of the US Tenerife consulate and simple residents were active in acquiring information about the islands defences. The transit of workers and construction materials were monitored and communicated in different ways. For limiting their activities, large island coast portions were declared military zones with strict access interdiction to the nearby farmers and inhabitants. During the construction of a battery in Gran Canaria, the Guardia Civil reported foreign subjects engaged in espionage activities (Defensa, 2015).

In Lanzarote $\left(29^{\circ} 2^{\prime} 19^{\prime \prime} \mathrm{N}, 13^{\circ} 39^{\prime} 1 \mathrm{~W}\right)$ (Figure 1), a battery, today disappeared, was built on 1941 at Punta Limones in Playa Blanca. It included a command bunker and Arisaka guns, which crossed their fire with that of the $150 \mathrm{~mm}$ Ordoñez mod. 1885 guns of the Corralejo battery in Fuerteventura for controlling La Bocayna channel between the two islands. The $107 \mathrm{~mm}$ Arisaka Meiji mod. 38 gun was the Japanese modified version of the $100 \mathrm{~mm}$ Krupp mod. 1904 gun, 
built on 1914 under licence by Arisaka in 120 exemplars for the Russian Army. During the Spanish Civil War 74 of these guns were used by the People's Republican Army (Ejército Popular de la República-EPR) and passed to the Spanish Army after the Civil War conclusion. Notwithstanding their range of $12 \mathrm{~km}$, because of their rare calibre and their reduced number, they were destined to the coastal defence from the Canaries up to Fernando Poo Island. Another battery was already built at Mirador del Rio as consequence of the Hispano-American war of 1898, based on $150 \mathrm{~mm}$ Ordoñez mod. 1885 guns. It remained as reserve up to 1940 when the bad preservation state of its guns rendered problematic its reactivation. In this period various ameliorations were made including the construction of a command bunker (Defensa, 2015). According to another source (Axis, 2012) two batteries were present at Mirador del Rio at that time, the first provided with $2 \times 76 \mathrm{~mm}$ guns and the second with $4 \times 210 \mathrm{~mm}$ howitzers.

In Lanzarote the coastal artillery comprised $4 \times 152 \mathrm{~mm}$ Putilov guns and $3 \times$ $107 \mathrm{~mm}$ Arisaka guns. The Putilov guns were a Russian version of a Schneider gun. They were sent by the URSS to the EPR during the Civil War. They had a range of $15 \mathrm{~km}$, but their reduced number, their not normalized calibre and the few ammunitions available caused them to be used for the coastal defence and retired in July 1942. In the island were built 75 bunkers, 25 double and 50 single, 56 machine gun nests and 5 casemates. The thick of the casemate walls were 80 $\mathrm{cm}$ up to $1 \mathrm{~m}$ for those much exposed to enemy landing (Defensa, 2015).

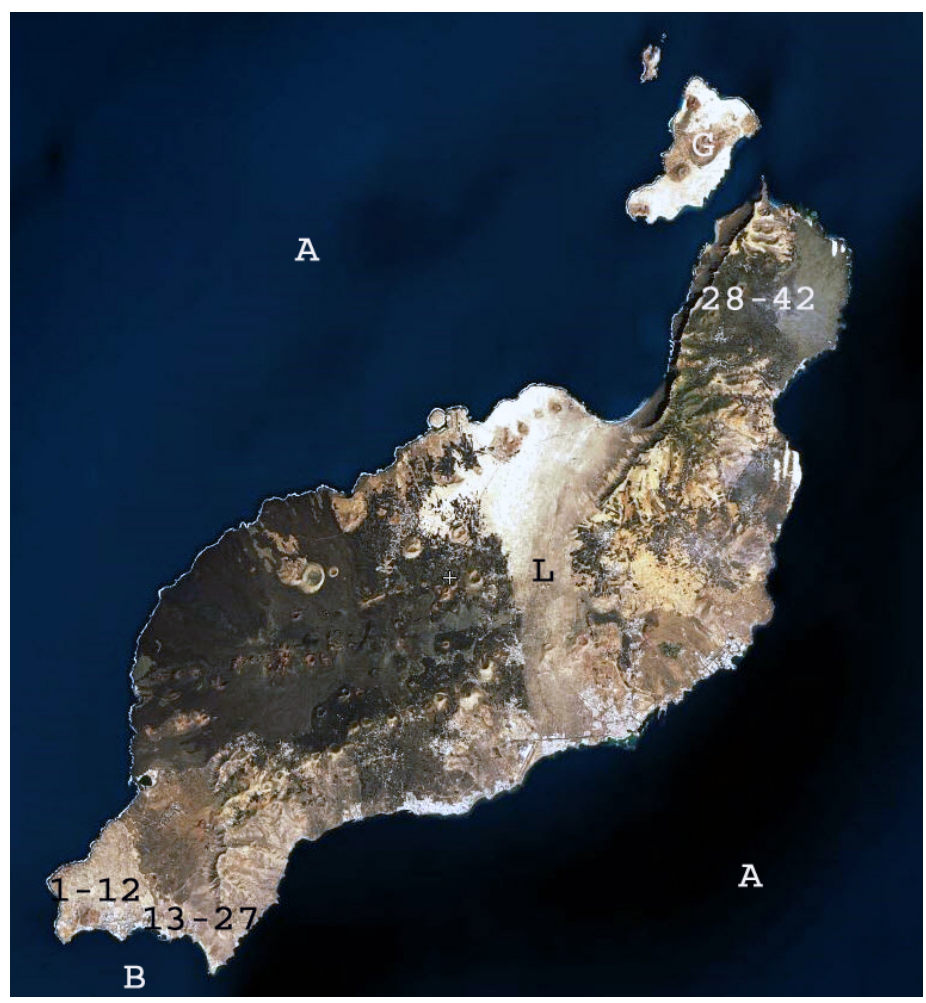

Figure 1. A Atlantic Ocean; B La Bocayna channel; L Lanzarote island; G La Graciosa island; 1 - 12 Playa Blanca coastal defences; 13 - 27 Punta del Papagayo coastal defences; 28 - 42 Mirador del Rio artillery bases (ZoomEarth). 
The denomination "pillbox" applied to casemates and bunkers is current in literature (Pillbox Study Group, 2016-2018) although its meaning is uncertain. In this article it will be applied to small, camouflaged bunkers provided with one or more fire apertures, encountered during the visits.

\section{Playa Blanca Coastal Defences}

The visit took place on $25^{\text {th }}$ November 2018 and, proceeding West to East; the identified military structures were the following.

A well preserved old lighthouse (1) (Figure 2) $\left(28^{\circ} 51^{\prime} 19.89^{\prime \prime} \mathrm{N}, 13^{\circ} 52^{\prime} 21.06^{\prime \prime} \mathrm{W}\right)$, built in local, magmatic, black breeks, composed by a one floor, square building about $20 \times 20 \mathrm{~m}$, and a protruding cylindrical light tower, about $10 \mathrm{~m}$ high and 4 $\mathrm{m}$ in diameter. The south facade had one window at each side of the light tower, the west facade had two windows, the north facade had an entrance and a window and the east facade had two windows and an entrance. All the windows were closed by breeks and a layer of concrete. The entrance on the east façade was closed by breeks with a superimposed concrete layer and the entrance on the north facade was closed by a brown painted, wood door. The interior was inaccessible; therefore, the internal room organization remained unknown. Satellite images show an internal, central square court. The facade walls were covered by recent graffiti. The flat roof had a balustrade and a protruding chimney at the corner between the east and the south facades. At the top, the tower preserved a white painted top circular portion in which an exit gave access to a circular balcony, and, superimposed, the metallic rests of the lamp house. No defensive structures were identified around the old lighthouse.

A well preserved truncated, pyramidal base (2) (Figure 3), $0.5 \mathrm{~m}$ high, $1.5 \mathrm{~m}$ each side at the base, $1 \mathrm{~m}$ each side at the top, built by local, small magmatic pebbles mixed with concrete (Tomezzoli, 2015a). A thin concrete layer covered portions of the side surfaces. No cylindrical, metallic shaft was at the centre of the top surface.

A well preserved truncated, truncated, pyramidal base (3) (Figure 4), $0.5 \mathrm{~m}$ high, $1.5 \mathrm{~m}$ each side at the base, $1 \mathrm{~m}$ each side at the top, built by local, small magmatic pebbles mixed with concrete. A concrete thin layer covered the side

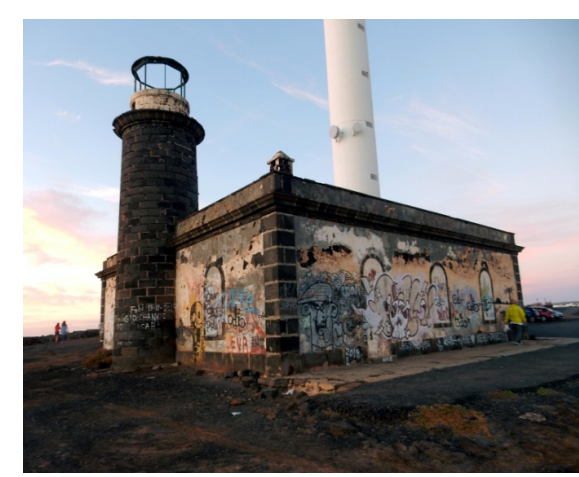

(a)

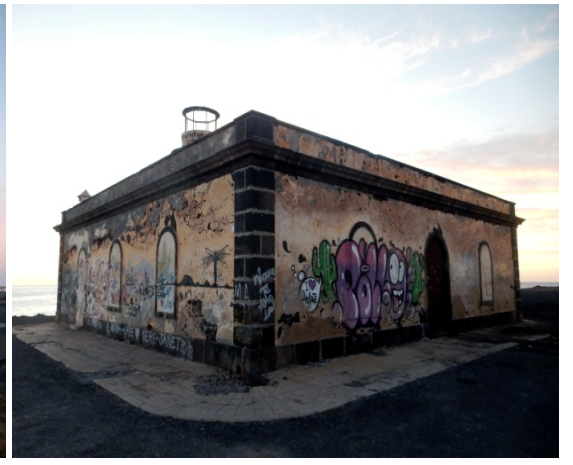

(b)

Figure 2. Old lighthouse (1)—(a) South and east facade; (b) East and north facade. 


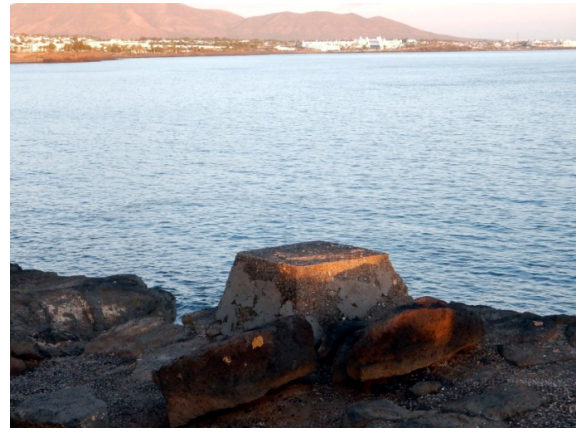

(a)

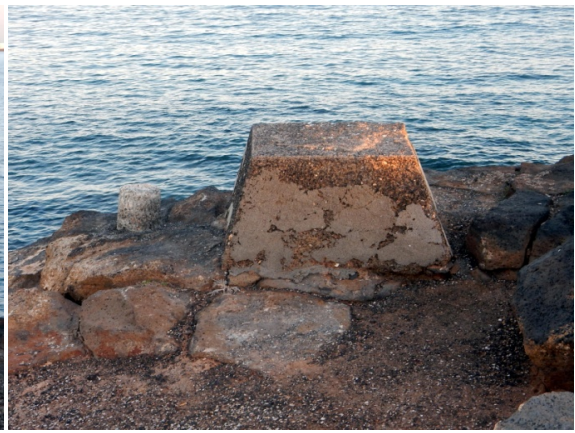

(b)

Figure 3. Truncated, pyramidal base (2)-(a) General view, on the foreground Playa Blanca; (b) Thin concrete layer covering portions of the side surfaces.

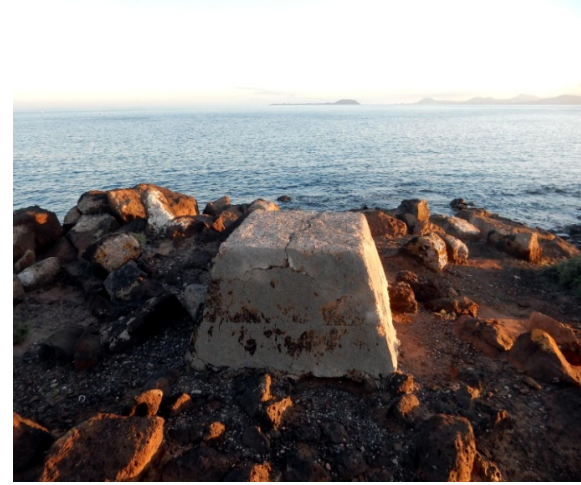

(a)

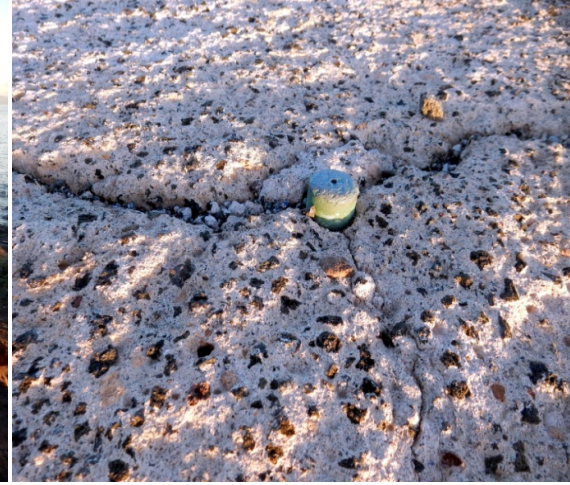

(b)

Figure 4. Truncated, pyramidal base (3)-(a) General view, on the foreground, Lobos island in the middle and Fuerteventura island on the right; (b) Local, small magmatic pebbles mixed with concrete and cylindrical, metallic shaft at the centre of the square top surface.

surfaces letting visible traces of the construction formwork. A cylindrical, metallic shaft, about $5 \mathrm{~cm}$ in diameter with a central hole slightly protruded at the centre of the top surface.

A well preserved one floor, rectangular pillbox bunker (4) $\left(28^{\circ} 51^{\prime} 38.76^{\prime \prime} \mathrm{N}\right.$, $13^{\circ} 51^{\prime} 30.81^{\prime \prime} \mathrm{W}$ ) (Figure 5), about $8 \times 5 \mathrm{~m}, 2.5 \mathrm{~m}$ high. Rather robust, it fallen from the cliff to the beach without structure damages. Its front facade had two fire apertures, about $30 \times 40 \mathrm{~cm}$, each with splinter guards and its rear facade had one entrance. The facades and the roof were covered by local, sea rounded magmatic stones. A single room formed its interior.

A quite well preserved truncated, pyramidal base (5) (Figure 6(a)), $0.5 \mathrm{~m}$ high, $1.2 \mathrm{~m}$ each side at the base, $1 \mathrm{~m}$ each side at the top, partially buried in the modern touristic promenade. It was built by local, small magmatic pebbles mixed with concrete. A thin concrete layer covered portions of the side surfaces. No cylindrical, metallic shaft was at the centre of the top surface.

A bad preserved truncated, pyramidal base (6) (Figure 6(b)), $0.5 \mathrm{~m}$ high, 1.5 $\mathrm{m}$ each side at the base, $1 \mathrm{~m}$ each side at the top, built by local, small magmatic pebbles mixed with concrete. Part of the top was lost letting visible internal bigger 


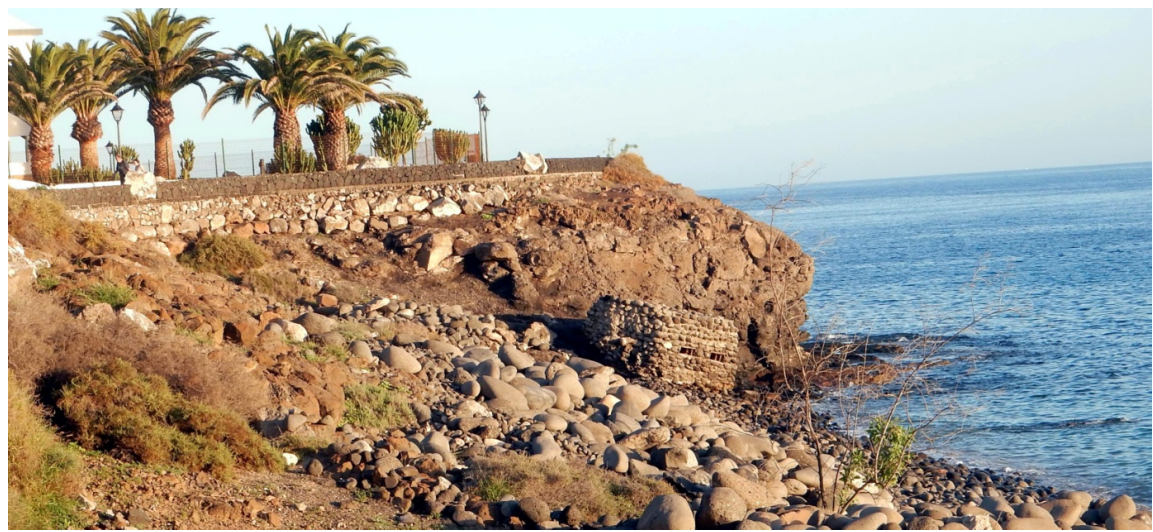

(a)

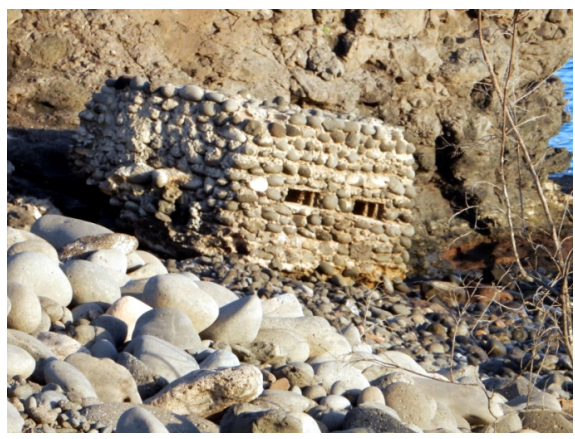

(b)

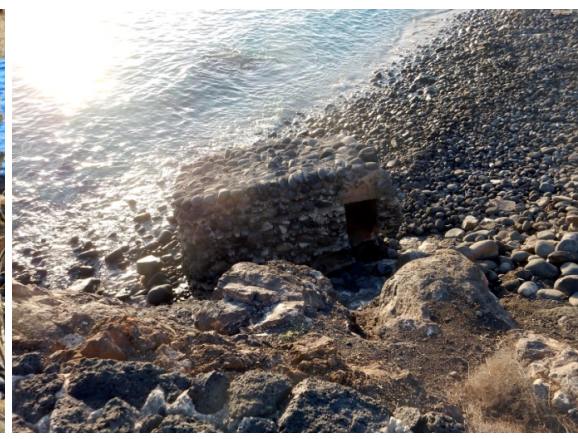

(c)

Figure 5. Pillbox (4) -(a) General view; (b) Front side with two fire apertures provided with splinter guards; (c) Rear side with entrance.

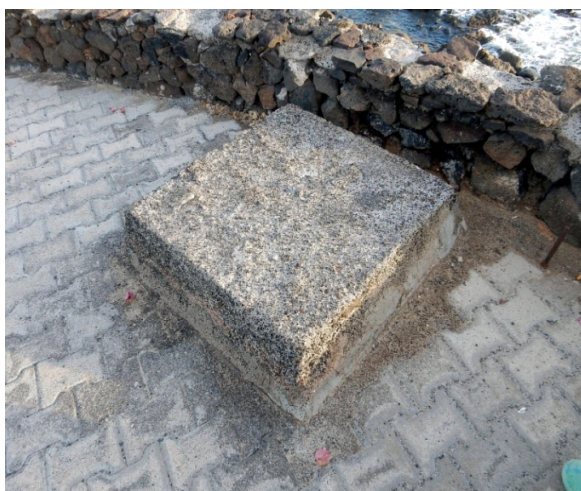

(a)

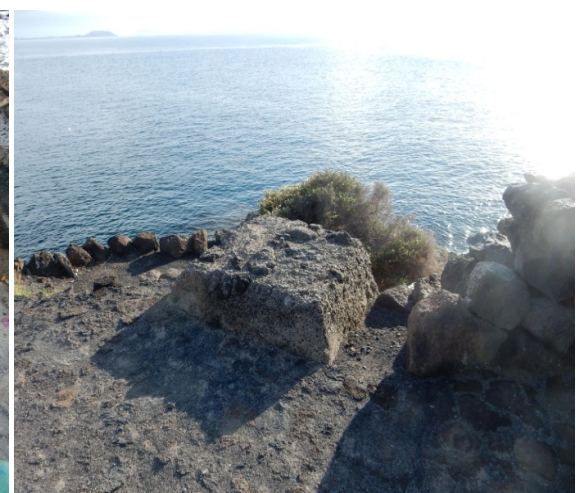

(b)

Figure 6. (a) Truncated, pyramidal base (5) general view; (b) Truncated, pyramidal base (6) on the foreground left Punta del Papagayo coast.

local, magmatic stones mixed with the concrete. A cylindrical, metallic shaft, about $5 \mathrm{~cm}$ in diameter with a central hole slightly protruded at the centre of the top surface.

A well preserved two floors, bunker (7) $\left(28^{\circ} 51^{\prime} 22.84^{\prime \prime} \mathrm{N}, 13^{\circ} 50^{\prime} 25.5^{\prime \prime W}\right)$ (Figure 7) at Punta Limones. Its entrance on its rear side, on the touristic promenade, was closed by an iron gate letting the interior inaccessible. However, the entrance let visible an access stair toward an underground floor. Local, magmatic, 
well placed black breeks were visible on the stair sides. The underground floor room organization remained unknown. Another stair from the underground floor gave access to the single room of its emerging portion, the floor of

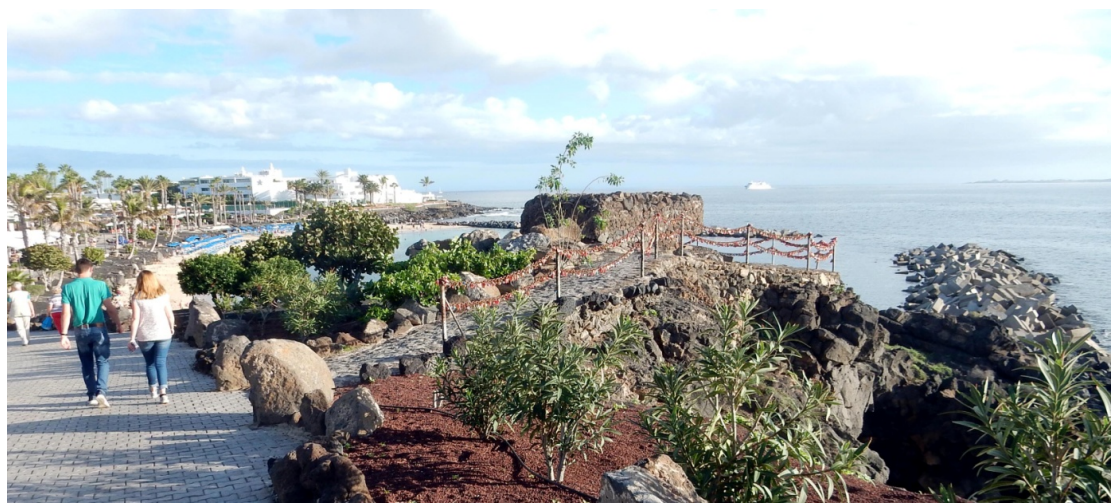

(a)

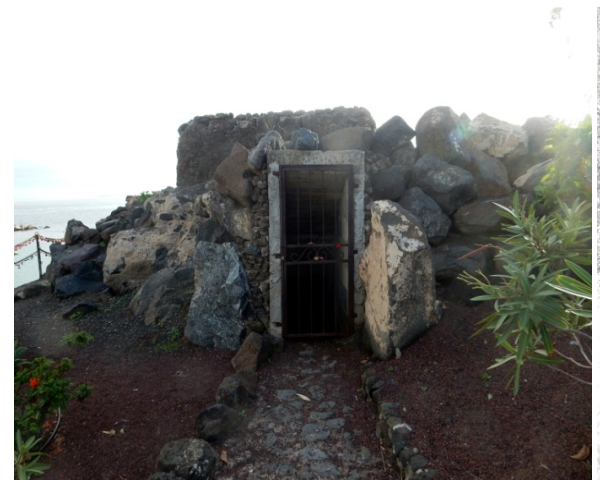

(b)

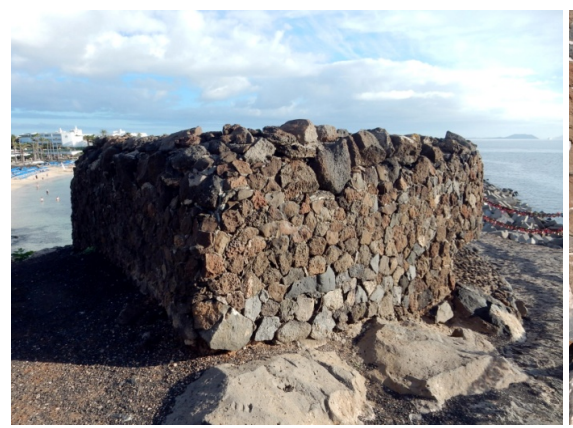

(d)

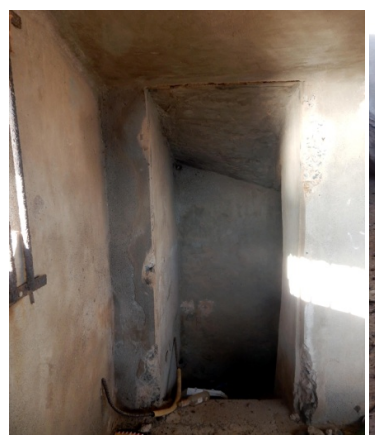

(f)

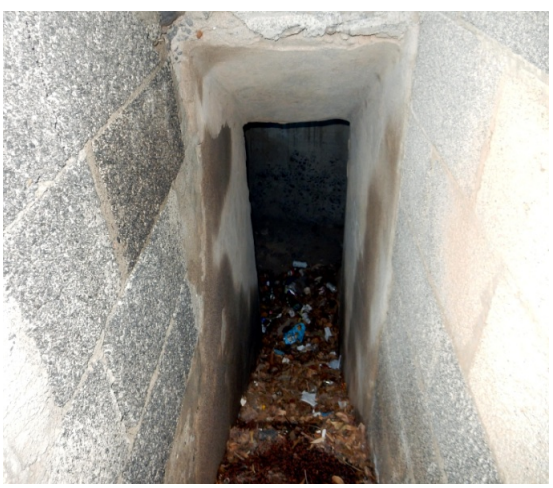

(c)

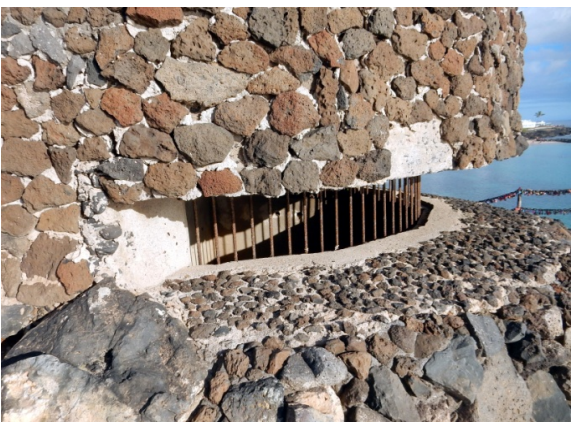

(e)

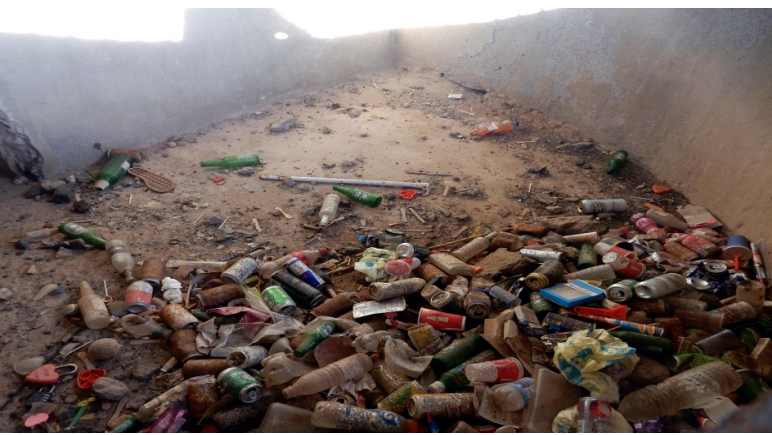

(g) 


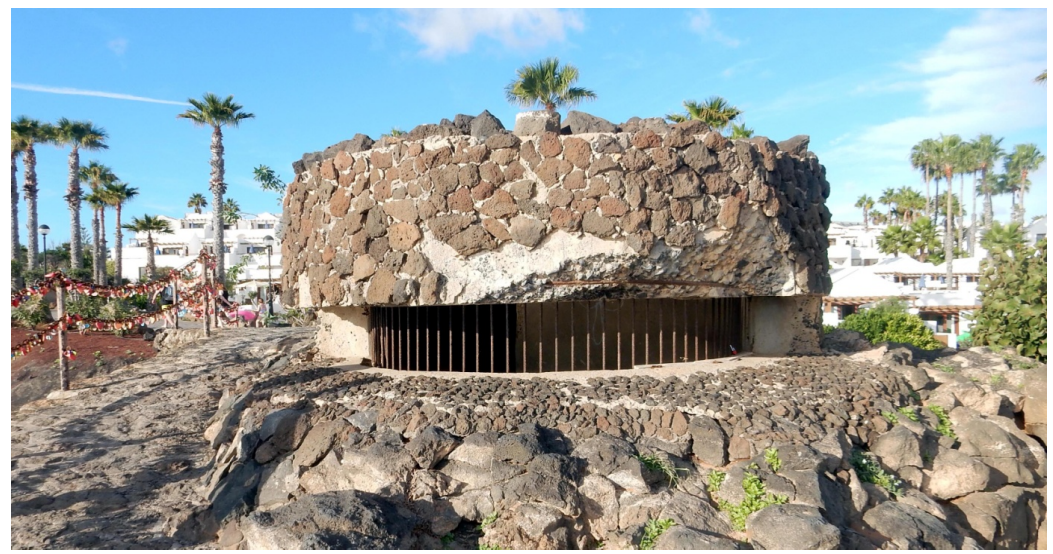

(h)

Figure 7. Punta Limones bunker (7)-(a) General view; (b) Rear side with entrance closed by an iron gate; (c) Entrance stair; (d) Emerging portion; (e) Front aperture of the single room; (f) Entrance in the single room; (g) Single room floor; (h) Bunker front side.

which was partially invaded by trash and had no trace of a gun or projector basement. The single, $180^{\circ}$ room aperture was closed by cylindrical shafts. The bunker interior preserved its original white painting. The emerging portion and its coverage were camouflaged with local, magmatic stones, but a collapsed, upper portion of the aperture let visible its armoured concrete structure. The possible rests of the battery of Punta Limones, if any, were buried or destroyed during the construction of a nearby, modern touristic apartment complex.

A ground emplacement (8) $\left(28^{\circ} 51^{\prime} 19.96^{\prime \prime} \mathrm{N}, 13^{\circ} 48^{\prime} 38.91^{\prime \prime W}\right)$ (Figure 8) located in front of the 1769 Castillo del Áquila ( $\left.28^{\circ} 51^{\prime} 21.12^{\prime \prime} \mathrm{N}, 13^{\circ} 48^{\prime} 38.68^{\prime \prime W}\right)$. It was formed by a trench about $6 \mathrm{~m}$ long, $2 \mathrm{~m}$ large connected to a circular cavity about $6 \mathrm{~m}$ in diameter.

A well preserved one floor, rectangular pillbox (9) $\left(28^{\circ} 51^{\prime} 28.03^{\prime \prime} \mathrm{N}, 13^{\circ} 47^{\prime}\right.$ $55.67 " \mathrm{~W}$ ) (Figure 9(a)), about $5 \times 4 \mathrm{~m}$, partially buried in the terrain. The entrance and the single fire aperture were buried in the terrain, so that the inspection of its interior was not possible. Its facades and coverage were camouflaged with local, rounded magmatic stones, and a thin, horizontal concrete layer covered a portion of the front facade.

A well preserved one floor, rectangular pillbox (10) $\left(28^{\circ} 51^{\prime} 27.44^{\prime \prime} \mathrm{N}, 13^{\circ} 47^{\prime}\right.$ $55.23 \mathrm{~W}$ ) (Figure 9(b)), about $5 \times 4 \mathrm{~m}$, partially buried in the terrain. The entrance and the single fire aperture with splinter guards were buried in the terrain, so that the inspection of its interior was not possible. Its facades and coverage were camouflaged with local, rounded magmatic stones.

A possible, circular ground emplacement (11) (Figure 9(c)), about $3 \mathrm{~m}$ in diameter was on a side of the pillbox (10).

A well preserved truncated, pyramidal base (12) (Figure 9(d)), $0.5 \mathrm{~m}$ high, 1.5 $\mathrm{m}$ each side at the base, $1 \mathrm{~m}$ each side at the top, built by local, small magmatic pebbles mixed with concrete, letting visible traces of the construction formwork. A cylindrical, metallic shaft, about $5 \mathrm{~cm}$ in diameter with a central hole slightly protruded at the centre of the top surface. 


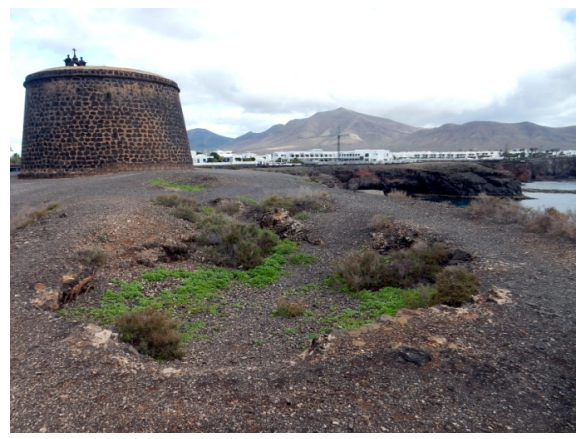

(a)

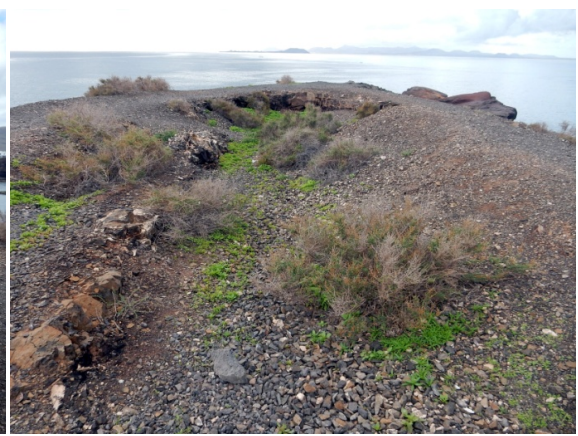

(b)

Figure 8. Ground emplacement (8)-(a) General view, on the foreground Castillo del Áquila on the left and Playa Blanca; (b) Access trench, on the foreground Lobos and Fuerteventura.

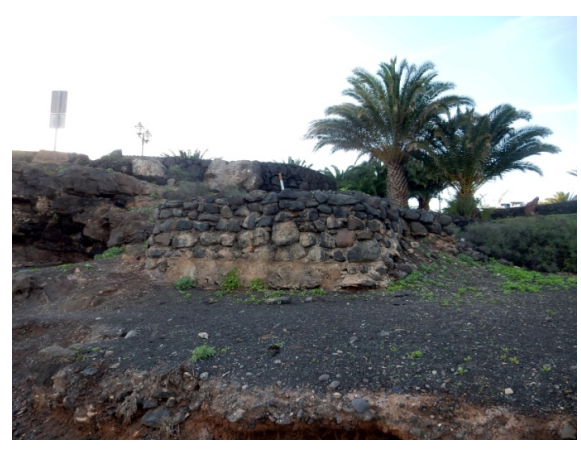

(a)

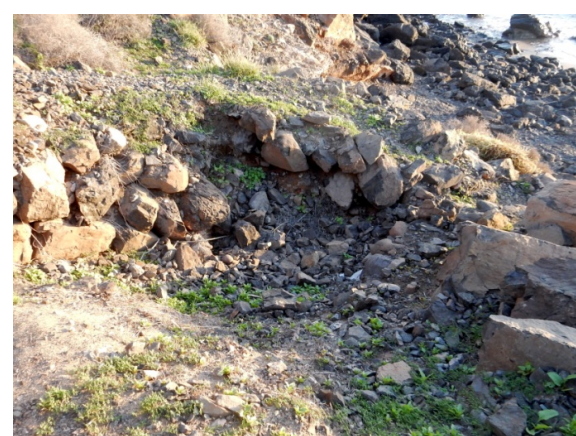

(c)

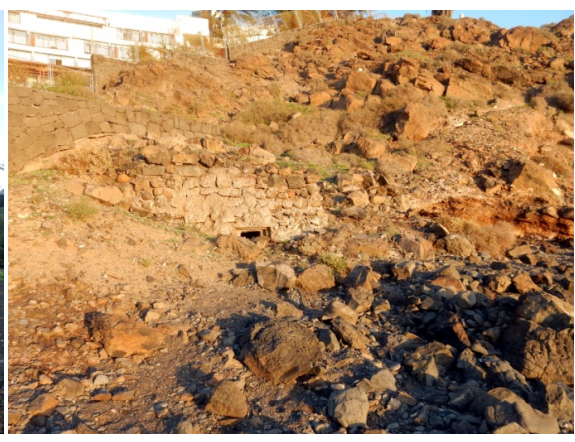

(b)

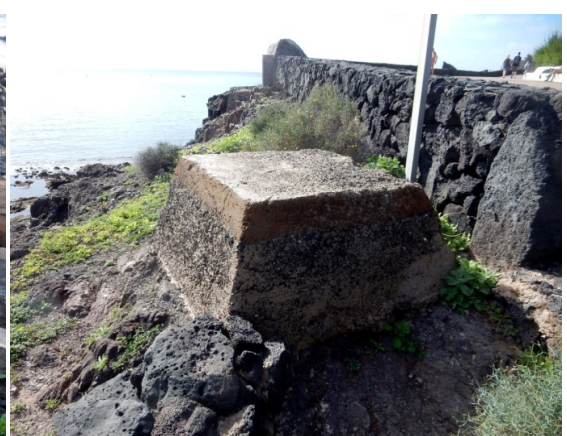

(d)

Figure 9. (a) Pillbox (9) front side; (b) Pillbox (10) front side with fire aperture provided with splinter guards; (c) Possible ground emplacement (11) on a side of the pillbox (10); (d) Truncated, pyramidal base (12).

\section{Punta Del Papagayo Coastal Defences}

The visit took place on $27^{\text {th }}$ November 2018 and continuing toward East the identified military structures were the following.

A well preserved truncated, pyramidal base (13) $\left(28^{\circ} 51^{\prime} 25.1^{\prime \prime} \mathrm{N}, 13^{\circ} 47^{\prime} 54.46^{\prime \prime} \mathrm{W}\right)$ (Figure 10(a)), $0.5 \mathrm{~m}$ high, $1.5 \mathrm{~m}$ each side at the base, $1 \mathrm{~m}$ each side at the top, built by local, small magmatic pebbles mixed with concrete, letting visible traces of the construction formwork. A scratch on one side let visible a portion of its internal armored concrete. A cylindrical, metallic shaft, about $5 \mathrm{~cm}$ in diameter 
with a central hole slightly protruded at the centre of the top surface.

A ground emplacement (14) $\left(28^{\circ} 51^{\prime} 18.2^{\prime \prime N}, 13^{\circ} 47^{\prime} 50.75^{\prime \prime W}\right)$ (Figures 10(b)-(d)) located at a cliff edge. It was formed by a two central, circular cavities about $5 \mathrm{~m}$ in diameter, each connected to an external, semi-circular trench following the cliff edge.

A well preserved truncated, pyramidal base (15) (Figure 10(e)), $0.5 \mathrm{~m}$ high, $1.5 \mathrm{~m}$ each side at the base, $1 \mathrm{~m}$ each side at the top, built by local, small magmatic pebbles mixed with concrete, letting visible traces of the construction formwork. A cylindrical, metallic shaft, about $5 \mathrm{~cm}$ in diameter with a central hole slightly protruded at the centre of the top surface.

A well preserved, white painted geodetic stone (16) (Figure 10(f)) formed by a cubic base with a superimposed cylinder. An oval, green plate on the base informed:

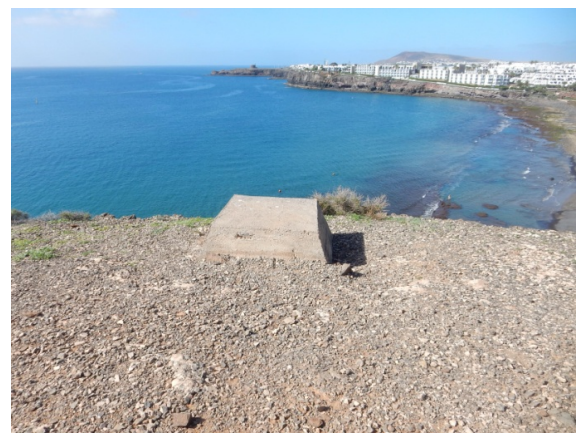

(a)

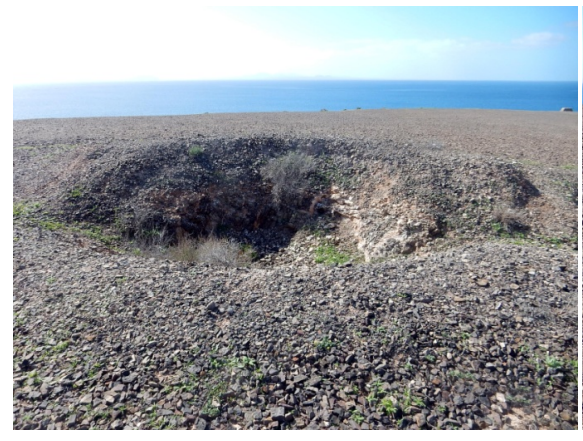

(c)

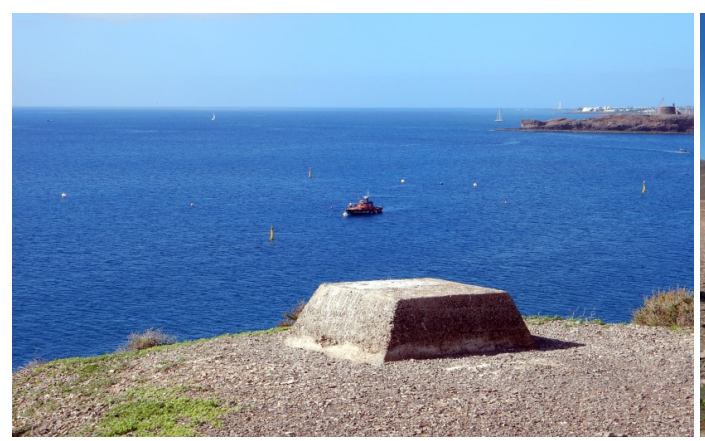

(e)

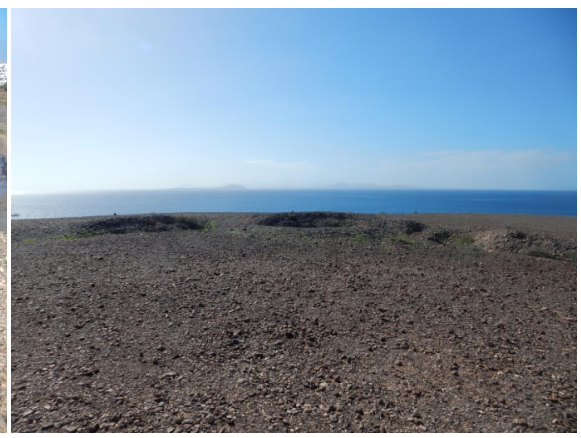

(b)

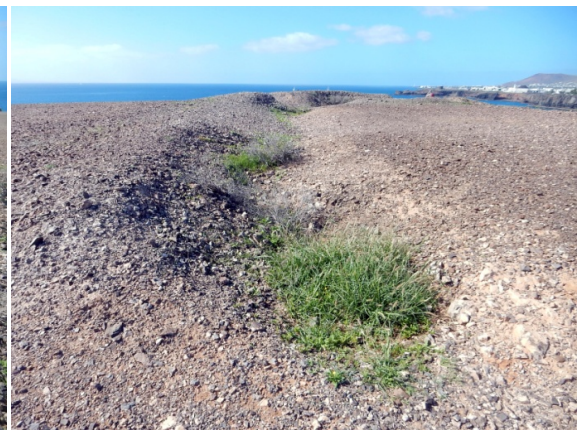

(d)

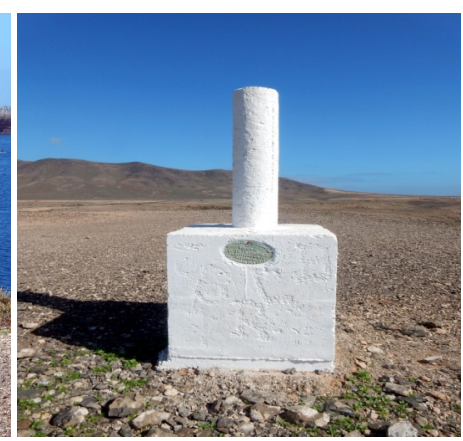

(f)

Figure 10. (a) Truncated, pyramidal base (13) General view, in the foreground Playa Blanca and Castillo del Áquila; (b)-(d) Ground emplacement (14); (e) Truncated, pyramidal base (15), in the foreground Castillo del Áquila; (f) Geodetic stone (16). 


\section{INSTITUTO GEOGRAFICO NACIONAL VÉRTICE GEODESICO}

\section{LA DESTRUCCION DE EST ASEGNALESTA' PENADA POR LA LEY}

without indication of the construction date.

A well preserved one floor, rectangular pillbox (17) $\left(28^{\circ} 51^{\prime} 16.77^{\prime \prime} \mathrm{N}, 13^{\circ} 47^{\prime}\right.$ $31.91 \mathrm{lW}$ ) (Figure 11(a)), about $5 \times 4 \mathrm{~m}$, near Playa Mujeres. Its entrance was on a road and had a single fire aperture directed toward the beach. Its facades and coverage were camouflaged with local, rounded magmatic stones.

A well preserved truncated, pyramidal base (18) (Figure 11(b)), $0.5 \mathrm{~m}$ high, $1.5 \mathrm{~m}$ each side at the base, $1 \mathrm{~m}$ each side at the top, built by local, small magmatic pebbles mixed with concrete, letting visible traces of the construction formwork. No cylindrical, metallic shaft was at the centre of the top surface.

A well preserved one floor, rectangular pillbox (19) $\left(28^{\circ} 51^{\prime} 15.22^{\prime \prime} \mathrm{N}, 13^{\circ} 47^{\prime}\right.$

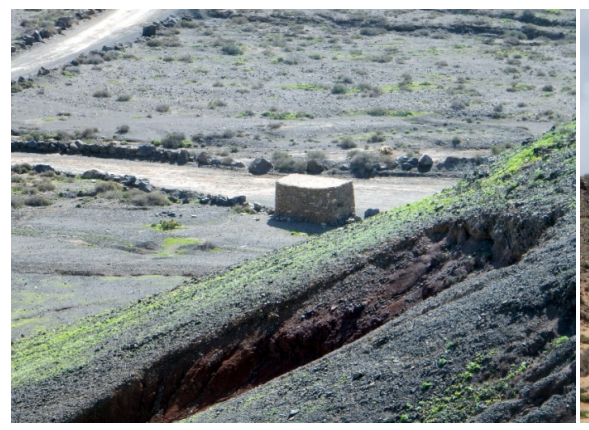

(a)

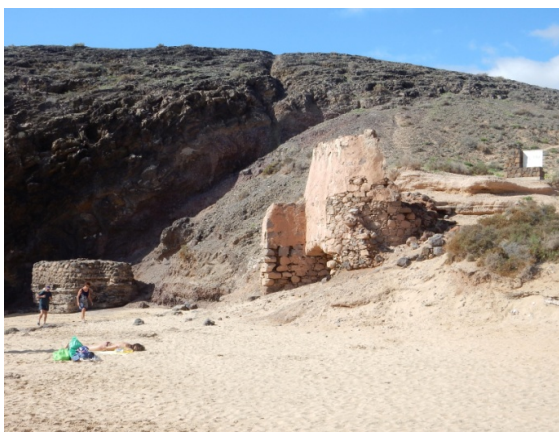

(c)

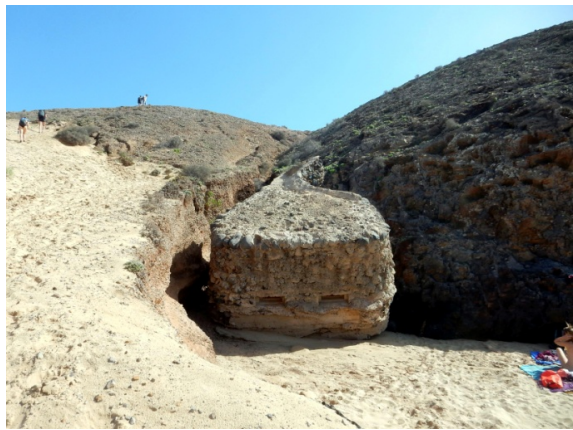

(e)

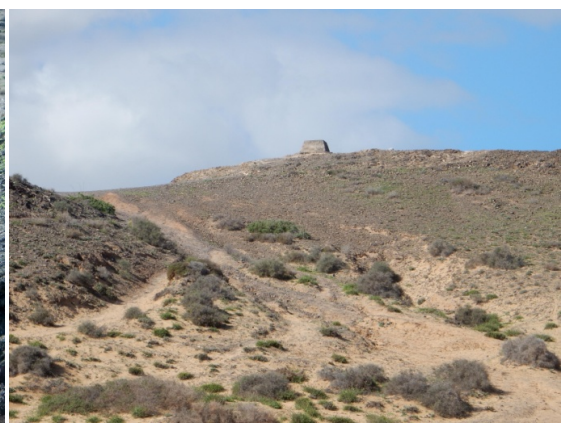

(b)

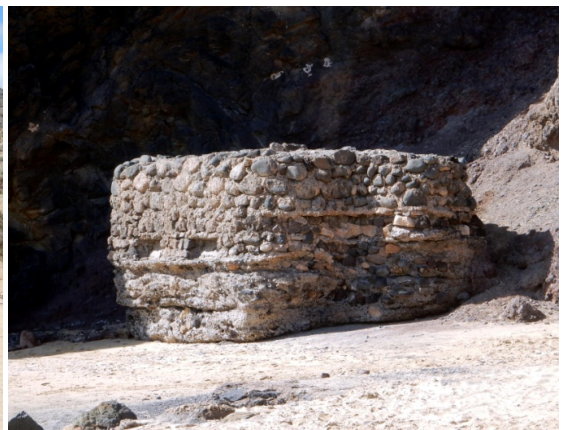

(d)

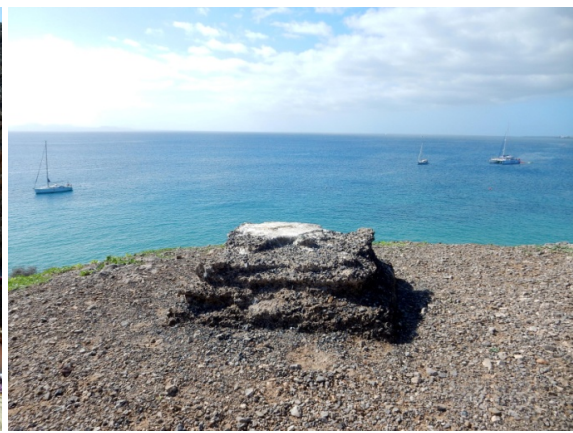

(f)

Figure 11. (a) Pillbox (17) near Playa Mujeres, general view; (b) Truncated, pyramidal base (18); (c)-(d) Pillbox (19) at Playa Mujeres near a middle-age guard tower; (e) Pillbox (20) at Playa Mujeres, general view; (f) Truncated, pyramidal base (21). 
40.04"W) (Figure 11(c) \& Figure 11(d)), about $8 \times 5 \mathrm{~m}, 2.5 \mathrm{~m}$ high, at the East side of Playa Mujeres. Its front facade had two fire apertures about $30 \times 40 \mathrm{~cm}$, without splinter guards and its rear facade had one entrance. The facades and the coverage were camouflaged with local, sea rounded magmatic stones. A single room without furniture formed its interior.

A well preserved one floor, rectangular pillbox (20) $\left(28^{\circ} 51^{\prime} 5.26^{\prime \prime} \mathrm{N}, 13^{\circ} 47^{\prime}\right.$ $30.75 \mathrm{~W}$ ) (Figure 11(e)), about $8 \times 5 \mathrm{~m}, 2.5 \mathrm{~m}$ high, at the West side of Playa Mujeres. Rather solid, it fallen from the cliff to the beach without structure damages. Its front facade had two fire apertures, about $30 \times 40 \mathrm{~cm}$, each with splinter guards, the rear façade was buried in the terrain. The facades and the coverage were camouflaged with local, sea rounded magmatic stones. A concrete layer was under the apertures.

A bad preserved truncated, pyramidal base (21) (Figure 11(f)), $0.5 \mathrm{~m}$ high, 1.5 $\mathrm{m}$ each side at the base, $1 \mathrm{~m}$ each side at the top, built by local, small magmatic pebbles mixed with concrete. Part of the top was lost. The sides were deeply eroded letting visible layers corresponding to the construction formwork. A cylindrical, metallic shaft, about $5 \mathrm{~cm}$ in diameter with a central hole slightly protruded at the centre of the top surface.

A well preserved one floor, rectangular pillbox (22) $\left(28^{\circ} 51^{\prime} 0.74^{\prime \prime} \mathrm{N}, 13^{\circ} 47^{\prime}\right.$ $28.98 \mathrm{"W}$ ) (Figures $12(\mathrm{a})-(\mathrm{c})$ ), about $8 \times 5 \mathrm{~m}, 2.5 \mathrm{~m}$ high, leaning against the cliff and partially buried in the sand. Its front facade had two fire apertures, about 30 $\times 40 \mathrm{~cm}$, without splinter guards and its side facade had one entrance. The facades

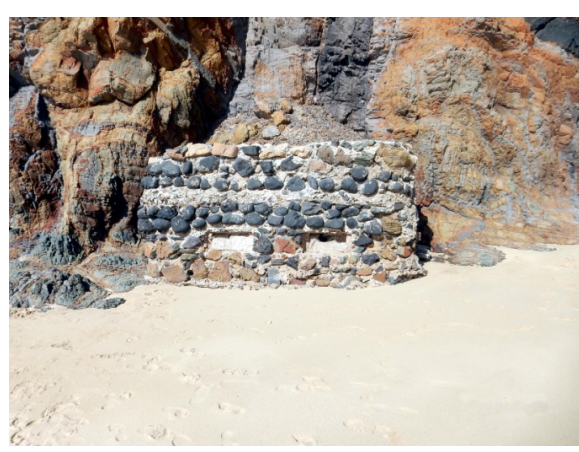

(a)

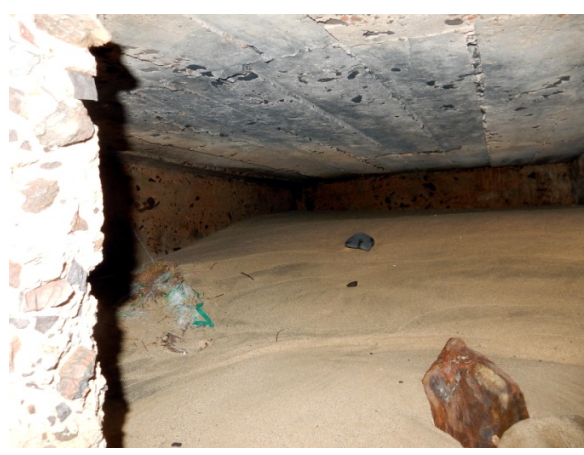

(c)

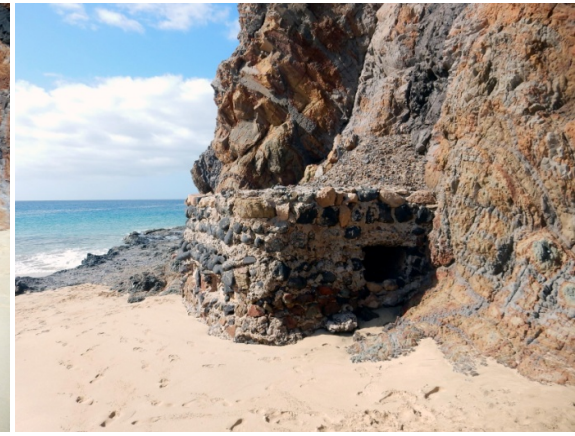

(b)

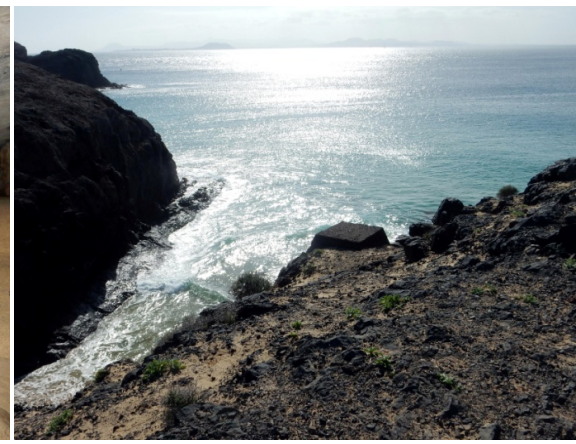

(d)

Figure 12. (a) Pillbox (22) front side view; (b) Pillbox (22) rear side view; (c) Pillbox (22) interior view; (d) Truncated, pyramidal base (23). 
and the coverage were camouflaged with local, sea rounded magmatic stones. The sand invaded the single room of its interior. The walls appeared orange coloured; on the ceiling the traces of the construction formwork were clearly visible.

A well preserved truncated, pyramidal base (23) $\left(28^{\circ} 50^{\prime} 58.59^{\prime \prime} \mathrm{N}, 13^{\circ} 47^{\prime} 27.26^{\prime \prime} \mathrm{W}\right)$ (Figure 12(d)), $0.5 \mathrm{~m}$ high, $1.5 \mathrm{~m}$ each side at the base, $1 \mathrm{~m}$ each side at the top, built by local, small magmatic pebbles mixed with concrete. A cylindrical, metallic shaft, about $5 \mathrm{~cm}$ in diameter with a central hole slightly protruded at the centre of the top surface.

A well preserved one floor, rectangular pillbox (24) $\left(28^{\circ} 50^{\prime} 38.92 " \mathrm{~N}, 13^{\circ} 47^{\prime}\right.$ $20.21 \mathrm{~W}$ ) (Figures 13(a) \& Figure 13(b)), about $8 \times 5 \mathrm{~m}, 2.5 \mathrm{~m}$ high leaning

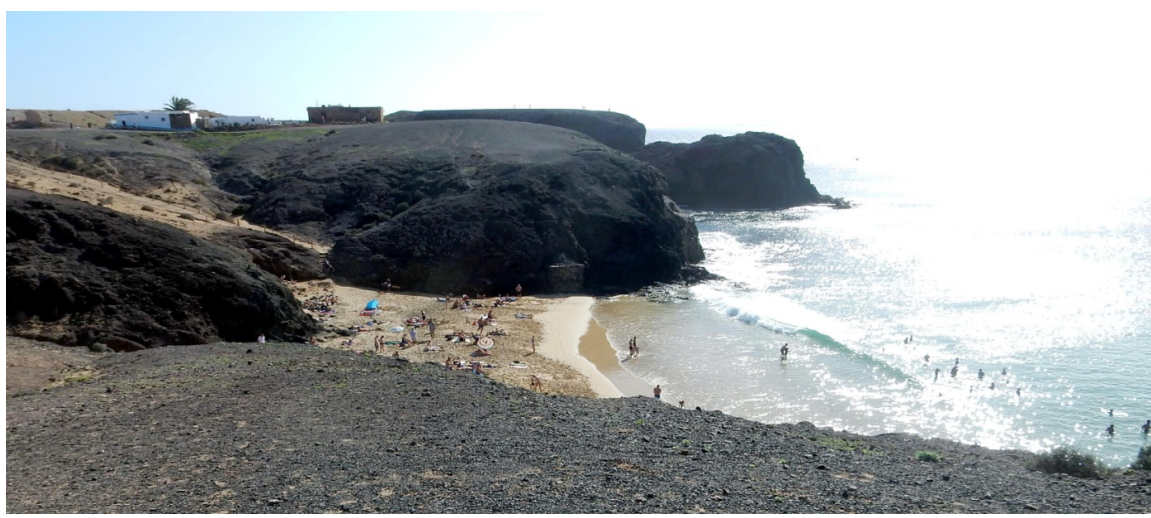

(a)

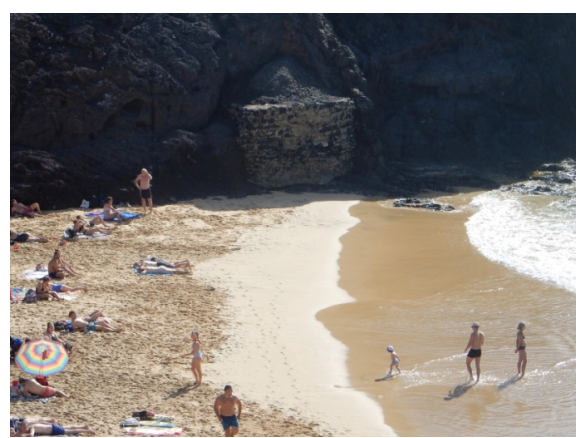

(b)

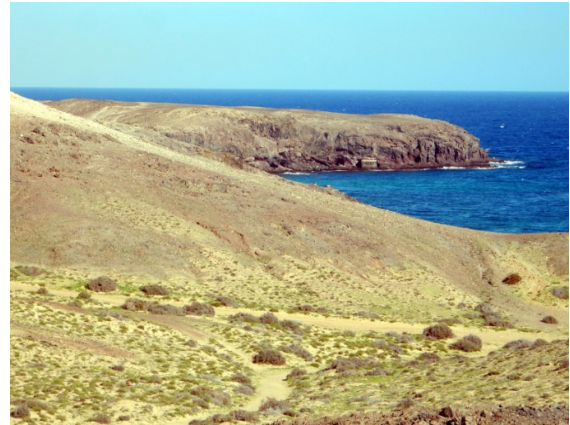

(d)

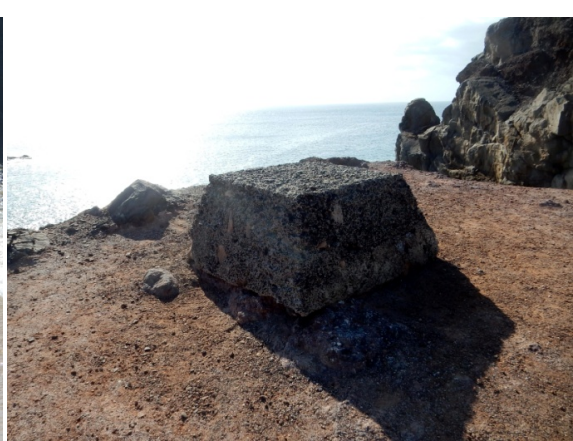

(c)

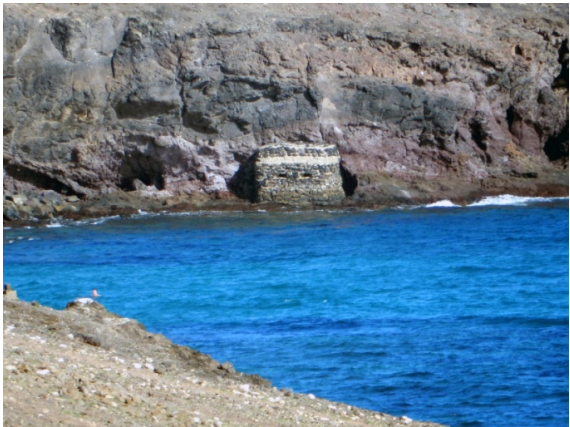

(e)

Figure 13. (a) Pillbox (24) general view; (b) Pillbox (24) front view; (c) Truncated, pyramidal base (25); (d) Pillbox (26) general view; (e) Pillbox (26) front view. 
against the cliff. Its front facade had two fire apertures, about $30 \times 40 \mathrm{~cm}$, without splinter guards. The facades and the coverage were camouflaged with local, sea rounded magmatic stones.

A well preserved truncated, pyramidal base (25) (Figure 13(c)), $0.5 \mathrm{~m}$ high, $1.5 \mathrm{~m}$ each side at the base, $1 \mathrm{~m}$ each side at the top, built by local, small magmatic pebbles mixed with concrete. A cylindrical, metallic shaft, about $5 \mathrm{~cm}$ in diameter with a central hole slightly protruded at the centre of the top surface.

A well preserved one floor, rectangular pillbox $(26)\left(28^{\circ} 50^{\prime} 37.11^{\prime \prime} \mathrm{N}, 13^{\circ} 46^{\prime}\right.$ $48.17 " \mathrm{~W}$ ) (Figure 13(d) \& Figure 13(e)), about $8 \times 5 \mathrm{~m}, 2.5 \mathrm{~m}$ high. Its front facade was provided with two fire apertures, about $30 \times 40 \mathrm{~cm}$, without splinter guards. The facades and the coverage were camouflaged with local, sea rounded magmatic stones. An elongated, concrete layer was above the apertures.

A well preserved bunker (27) $\left(28^{\circ} 50^{\prime} 24.69^{\prime \prime} \mathrm{N}, 13^{\circ} 47^{\prime} 16.57^{\prime \prime} \mathrm{W}\right)$ (Figure 14) completely buried in the terrain. Its entrance had an upper front side, formed by rounded magmatic stones allowing estimating at about $1 \mathrm{~m}$ the thickness of its coverage. A concrete, square pit, about $2 \times 2 \mathrm{~m}$ was at one side of the entrance. Local, small magmatic pebbles mixed with concrete were visible on the entrance stair sides. The stair introduced in a $1^{\text {st }}$ room with walls and ceiling formed by local, small magmatic pebbles mixed with concrete, letting visible traces of the construction formwork. A separation wall allowed entrance to a $2^{\text {nd }}$ room with walls and ceiling formed by local, small magmatic pebbles mixed with concrete, letting visible traces of the construction formwork. On one side a square column protruded from a wall in correspondence with another protruding square column

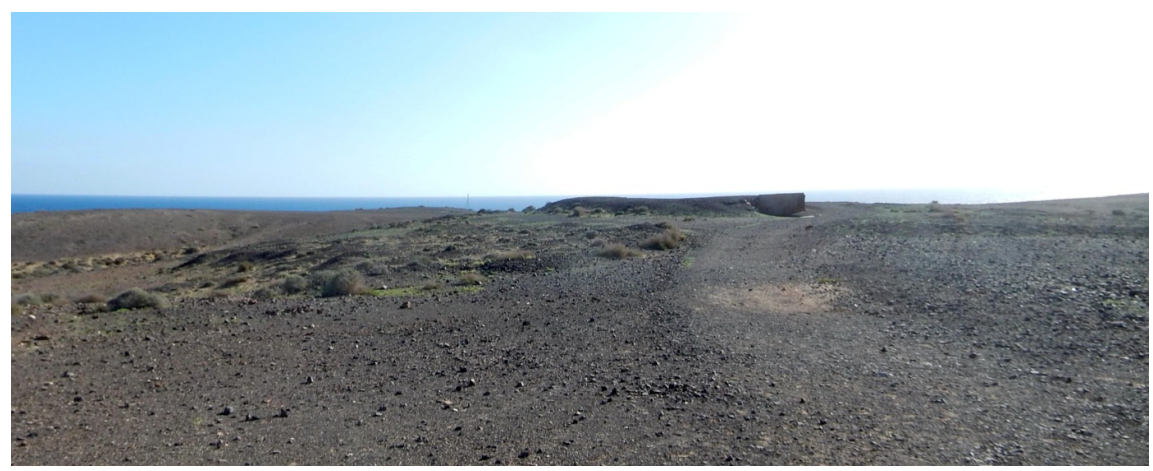

(a)

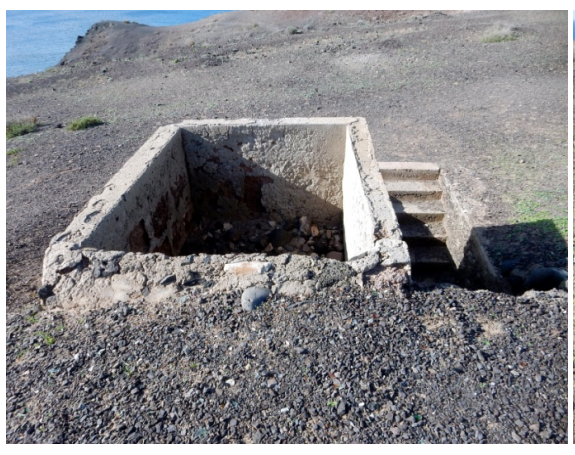

(b)

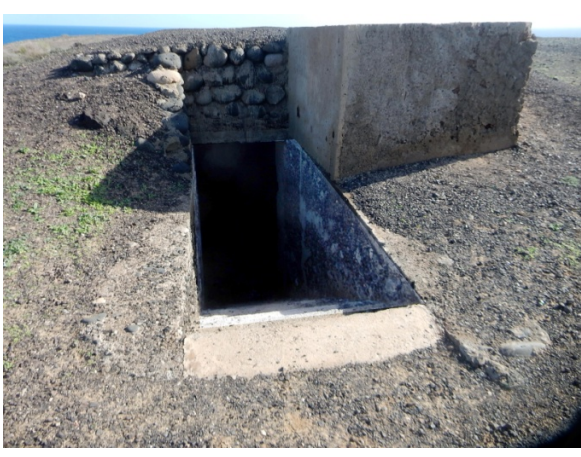

(c) 


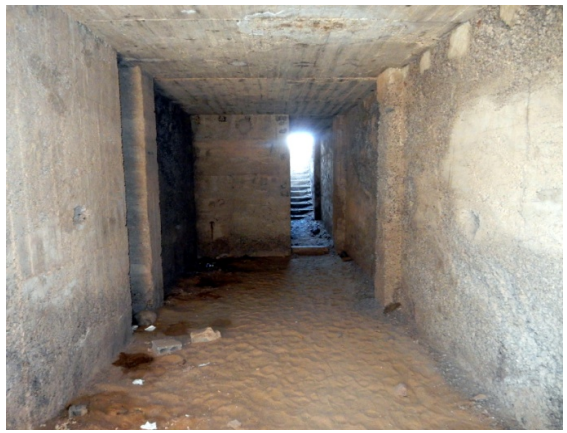

(d)

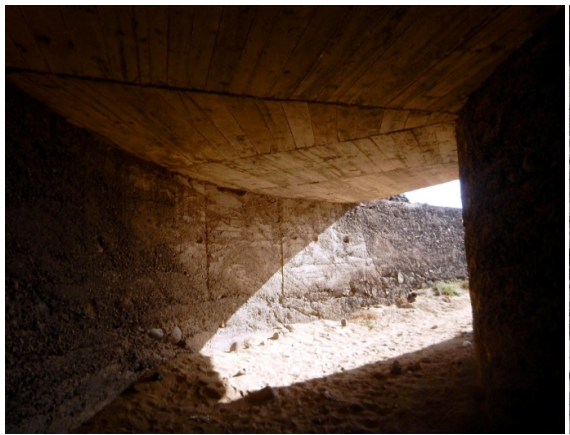

(f)

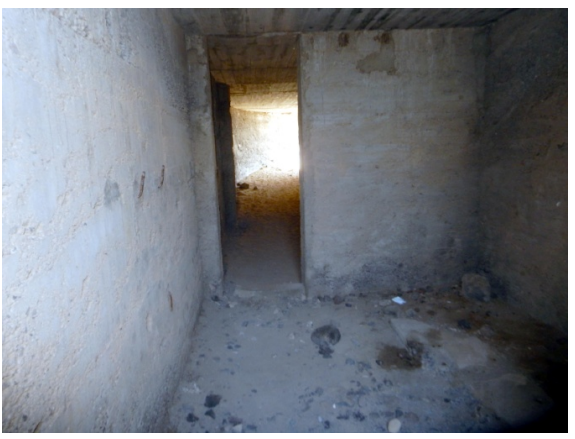

(e)

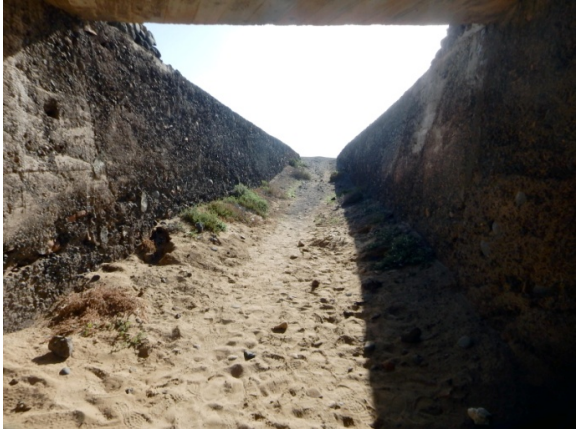

(g)

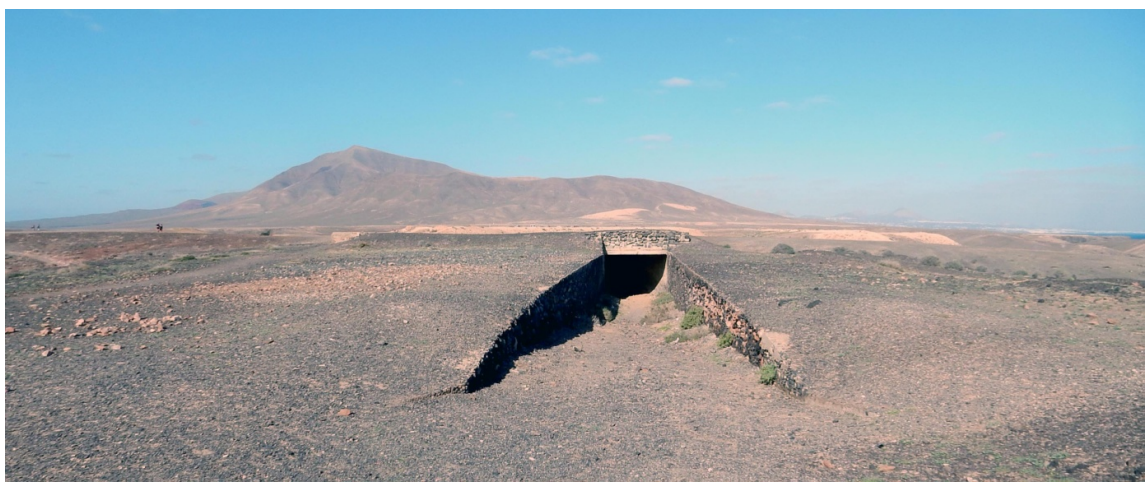

(h)

Figure 14. (a) Bunker (27) general view toward south; (b) Square pit and access stair; (c) Access stair with upper front side formed by rounded magmatic stones; (d) $2^{\text {nd }}$ room with protruding square columns and niche, in the middle, separation wall and access stair; (e) $2^{\text {nd }}$ room, on the left wall three curved fixation for a disappeared support or device, in the middle separation wall; (f) Curved exit; (g) Exit ramp with protective walls; (h) Bunker (26) general view toward north.

and a niche on the opposed wall. On one wall three, curved fixations joints and on the opposite wall four holes indicated disappeared supports or devices. A separation wall provided the entrance to a $3^{\text {rd }}$ room with walls and ceiling formed by local, small magmatic pebbles mixed with concrete, letting visible traces of the construction formwork. The $3^{\text {rd }}$ room gave access to a curved passage towards a ramp about $30 \mathrm{~m}$ long with protective side walls made by local, magmatic stones. The ramp floor appeared not provided with rails. The bunker interior preserved its original white painting. All the original furniture disappeared and no trace 
was visible of supports for an illumination system.

\section{Mirador Del Rio Artillery Batteries}

The visit took place on $29^{\text {th }}$ November 2018, but, unfortunately, the Mirador del Rio military structures (Figure 15) were on a terrain with access interdiction; therefore they were only indirectly identified. Satellite images permitted to recognize a $1^{\text {st }}$ battery (1) $\left(29^{\circ} 12^{\prime} 52.73^{\prime \prime} \mathrm{N}, 13^{\circ} 28^{\prime} 51.28^{\prime \prime} \mathrm{W}\right)$ and a $2^{\text {nd }}$ battery (2) $\left(29^{\circ} 12^{\prime} 52.73^{\prime \prime} \mathrm{N}, 13^{\circ} 28^{\prime} 51.28^{\prime \prime} \mathrm{W}\right)$. The identified structures (Figure 16) of the $1^{\text {st }}$ artillery battery (1), near the modern Mirador del Rio parking, were the following.

A well preserved oval emplacement (28) $\left(29^{\circ} 12^{\prime} 51.89^{\prime \prime} \mathrm{N}, 13^{\circ} 28^{\prime} 51.64^{\prime \prime} \mathrm{W}\right)$ (Figures $16(\mathrm{a})-(\mathrm{c})$ ), about $10 \times 8 \mathrm{~m}, 1.5 \mathrm{~m}$ deep. Its interior was partially covered by terrain and vegetation. On one side an entrance gave access to a corridor and an interior floor.

A buried rectangular bunker (29) $\left(29^{\circ} 12^{\prime} 52.33^{\prime \prime N}, 13^{\circ} 28^{\prime} 51.45^{\prime \prime W}\right)$ (Figure 16(a), Figure $16(\mathrm{~d})$ ), about $10 \times 6 \mathrm{~m}$. Its coverage appeared in a good preservation state.

A well preserved bunker (30) $\left(29^{\circ} 12^{\prime} 52.51^{\prime \prime} \mathrm{N}, 13^{\circ} 28^{\prime} 51.15^{\prime \prime W}\right)$ (Figure 16(d)) similar to the bunker (7) (Figure 7) at Punta Limones. Its emerging portion had a single room with a single $180^{\circ}$ aperture. The external surface of the emerging portion, except the rear side, and its coverage were camouflaged with local, magmatic stones. The presence of an underground floor was not possible to be ascertained.

A possible rectangular bunker (31) $\left(29^{\circ} 12^{\prime} 53.22^{\prime \prime} \mathrm{N}, 13^{\circ} 28^{\prime} 51.01^{\prime \prime W}\right)$ (Figure $16(\mathrm{a})$ ), about $10 \times 6 \mathrm{~m}$, on the cliff edge. Its coverage appeared in a good preservation state.

The identified structures of the $2^{\text {nd }}$ battery (Figure 17), about $300 \mathrm{~m}$ north from the $1^{\text {st }}$ battery, were the following.

A circular artillery emplacement (32) $\left(29^{\circ} 12^{\prime} 57.13^{\prime \prime} \mathrm{N}, 13^{\circ} 28^{\prime} 42.93^{\prime \prime W}\right)$ about $10 \mathrm{~m}$ in diameter, having a single entrance, without protection, wall toward the Lanzarote interior and a support for a gun at its centre.

A circular artillery emplacement (33) $\left(29^{\circ} 12^{\prime} 57.68^{\prime \prime} \mathrm{N}, 13^{\circ} 28^{\prime} 42.46^{\prime \prime W}\right)$ about

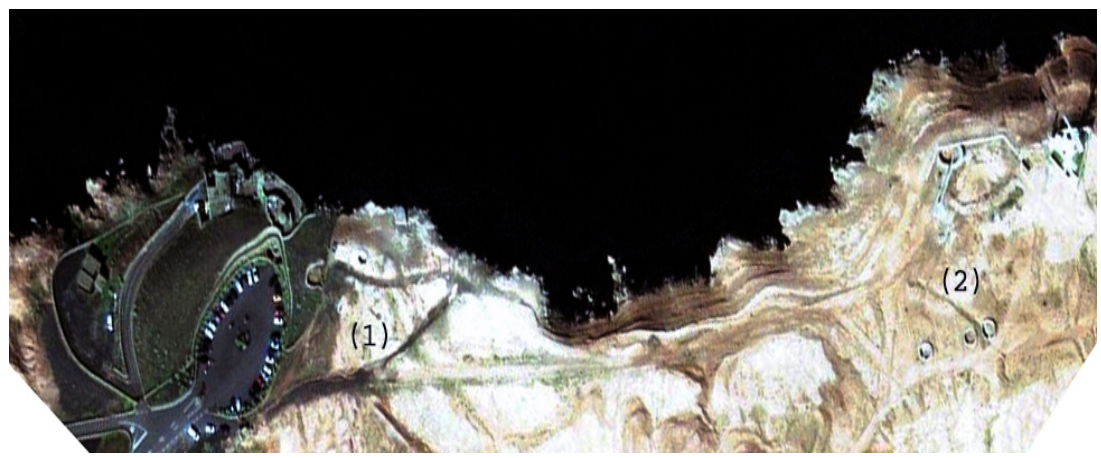

Figure 15. Mirador del Rio artillery batteries-(1) $1^{\text {st }}$ artillery battery; (2) $2^{\text {nd }}$ artillery battery (ZoomEarth). 


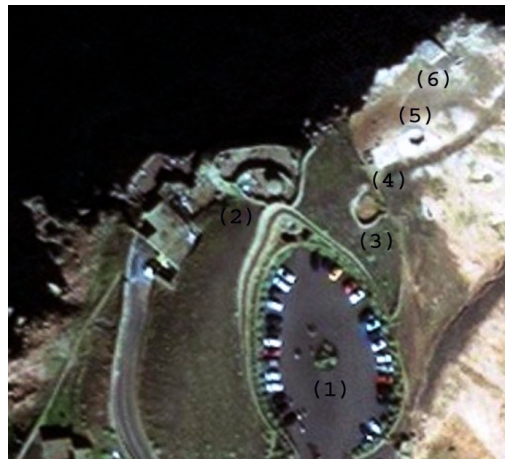

(a)

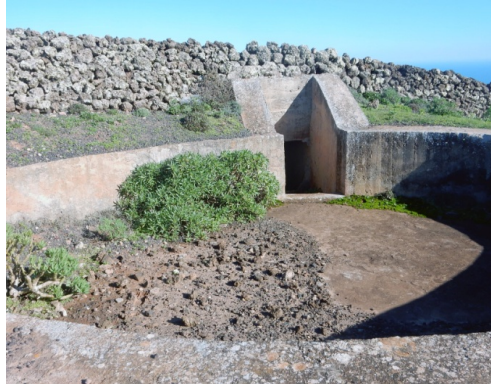

(c)

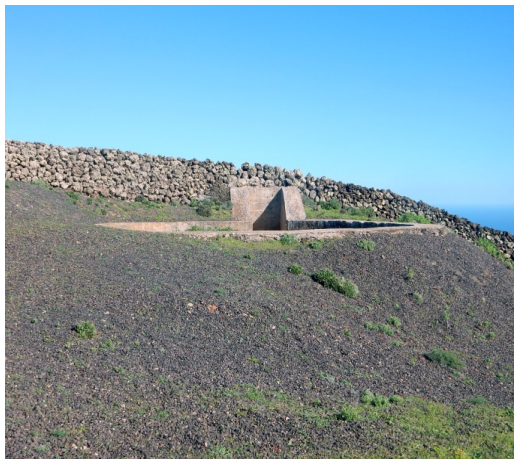

(b)

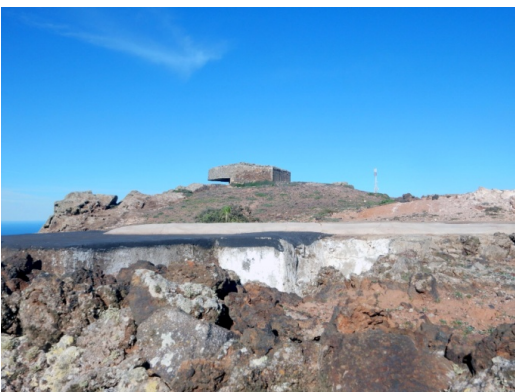

(d)

Figure 16. Mirador del Rio $1^{\text {st }}$ artillery battery-(a) 1st artillery battery components (ZoomEarth): (1) parking, (2) Mirador del Rio restaurant, (3) oval emplacement (28), (4) buried rectangular bunker (29), (5) bunker (30), (6) possible rectangular bunker (31); (b)-(c) Oval emplacement (28) with entrance to the interior floor; (d) Buried rectangular bunker (29), in the foreground, bunker (30).

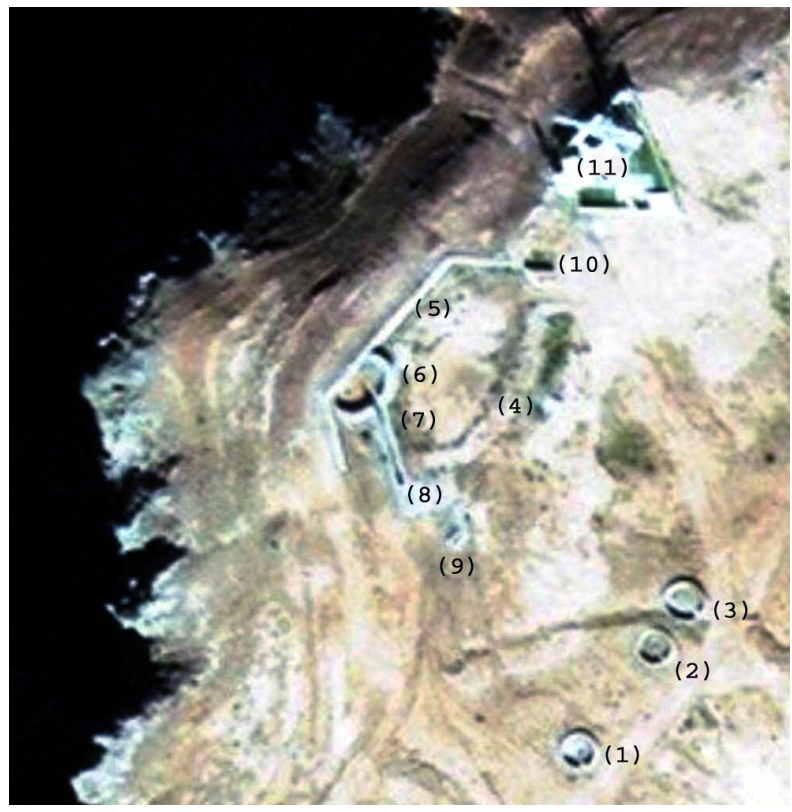

Figure 17. Mirador del Rio $2^{\text {nd }}$ artillery base-(1) circular artillery emplacement (32); (2) circular artillery emplacement (33); (3) circular artillery emplacement (34); (4) embankment (35); (5) three sided barrier wall (36); (6) oval artillery emplacement (37); (7) trench (38); (8) buried bunker (39); (9) small construction (40); (10) cistern (41); fort or modern house (42) (ZoomEarth). 
$10 \mathrm{~m}$ in diameter, having a single entrance, without protection wall, toward the Lanzarote interior and a support for a gun at its centre.

A circular artillery emplacement (34) $\left(29^{\circ} 12^{\prime} 57.94^{\prime \prime} \mathrm{N}, 13^{\circ} 28^{\prime} 42.28^{\prime \prime} \mathrm{W}\right)$ about $10 \mathrm{~m}$ in diameter, having a single entrance, without protection wall, toward the Lanzarote interior. It was located close to circular artillery emplacement (33) and a support for a gun at its centre was not clearly identifiable.

An arcuate embankment (35) $\left(29^{\circ} 12^{\prime} 52.33^{\prime \prime} \mathrm{N}, 13^{\circ} 28^{\prime} 51.45^{\prime \prime} \mathrm{W}\right)$.

A three sided barrier wall (36) $\left(29^{\circ} 12^{\prime} 59.43^{\prime \prime} \mathrm{N}, 13^{\circ} 28^{\prime} 44.05^{\prime \prime} \mathrm{W}\right)$ having a central portion about $40 \mathrm{~m}$ long on the cliff edge and two wings about $20 \mathrm{~m}$ long, each angled about $45^{\circ}$ with respect to the central portion. The three sided barrier wall (36) together with the arcuate embankment (35) formed a closed area.

An oval artillery emplacement (37) $\left(29^{\circ} 12^{\prime} 59.1^{\prime \prime} \mathrm{N}, 13^{\circ} 28^{\prime} 44.24^{\prime \prime} \mathrm{W}\right)$ about $15 \times$ $10 \mathrm{~m}$, leaning against the east side of the central portion of the three sided barrier wall (36), similar to the oval emplacement (28) but apparently without entrance to internal or underground rooms.

A trench (38) $\left(29^{\circ} 12^{\prime} 58.5^{\prime \prime} \mathrm{N}, 13^{\circ} 28^{\prime} 44.1^{\prime \prime} \mathrm{W}\right)$ about $30 \mathrm{~m}$ long.

A buried bunker (39) $\left(29^{\circ} 12^{\prime} 52.33^{\prime \prime} \mathrm{N}, 13^{\circ} 28^{\prime} 43.87^{\prime \prime} \mathrm{W}\right)$ about $10 \times 5 \mathrm{~m}$, similar to the bunkers (29), (31), connected by the trench (38) to the oval emplacement (37).

A small construction (40) $\left(29^{\circ} 12^{\prime} 58.27^{\prime \prime} \mathrm{N}, 13^{\circ} 28^{\prime} 43.68^{\prime \prime} \mathrm{W}\right)$ about $5 \times 3 \mathrm{~m}$.

An open cistern $(41)\left(29^{\circ} 12^{\prime} 59.75^{\prime \prime} \mathrm{N}, 13^{\circ} 28^{\prime} 43.15^{\prime \prime} \mathrm{W}\right)$ about $10 \times 5 \mathrm{~m}$.

A fort or modern house $(42)\left(29^{\circ} 13^{\prime} 0.27^{\prime \prime N}, 13^{\circ} 28^{\prime} 42.82^{\prime \prime} \mathrm{W}\right)$ contoured by a triangular wall about $30 \mathrm{~m}$ each side.

\section{Discussion}

The Lanzarote defences were composed mainly by pillboxes, truncated, pyramidal bases, ground emplacements and artillery bases.

The pillboxes were of simple project, easy and rapid to build. They were not built on island elevations from which dominate beaches and large spaces but letting them exposed and easy to identify. Rather, they were built low along the coasts or directly on the beaches. Normally, they were located at one side of short beaches, as pillboxes (22), (24), (26), or at both sides of longer beaches so as to cross their fire against landing forces, as the pillboxes (19)-(20) at the East and West sides of Playa Mujeres. The local, magmatic stones covering their surfaces reinforced the pillboxes structure and provided camouflage. This, combined with theirlocation increased their defensive effectiveness against landings and survival capacity. Their single, internal room functioned as close combat room and lodgement for a crew of at least an officer and three or four soldiers armed with personal, light machine guns. The pillboxes (9)-(10), (17), provided with a single fire aperture, correspond to single bunkers (Defensa, 2015). The pillboxes (4), (19)-(20), (22), (24), (26), provided with two fire apertures, correspond to double bunkers (Defensa, 2015). The recent construction formwork traces observed on the ceiling of pillbox (12) would indicate the pillbox con- 
struction in the period of the WWII.

The truncated, pyramidal bases, as (2)-(3), (5)-(6), (12)-(13), (15), (18), (21), (23), (25), because of their low, difficult to identify structure, were instead located on relatively elevated positions from which dominate beaches and large spaces. They were generally close to pillboxes for supporting their fire. The bases hosted probably one offensive and defensive or static defence machinegun served by two or three soldiers. However the way in which a machine gun was mounted on a truncated pyramidal base and the machine guns designated for said bases remain unknown.

The ground emplacements were located in relatively elevated positions to dominate large spaces were the fire of machine guns on said bases was judged insufficient. They offered better protection to one or two officers and about five to ten soldiers armed with personal machine guns and one or more offensive and defensive or static defence machine guns. The ground emplacements (8), (11), (13) correspond to machine gun nests (Defensa, 2015).

The two floors, bunker (7) corresponds to the command bunker of the Punta Limones battery (Defensa, 2015). The cylindrical shafts on the $180^{\circ}$ aperture were placed later after its construction. During the WWII the aperture was free, and the reduced room dimensions, the absence on its floor of a basement for a heavy gun or a projector suggests that it was mainly used for observation and fire direction of the battery. It probably hosted a telemeter although the presence of one or more defence machine gun mounted on its own bases for far and close defence cannot be excluded. Its armoured concrete structure confirms its construction during the WWII. The battery guns were field guns on their own carriage (Defensa, 2015), therefore they needed only circumstance places not necessarily artillery emplacements. The battery personnel lodged outside the bunker in disappeared barracks or tents.

The bunker (27) lodged personnel in the $1^{\text {st }}$ and $2^{\text {nd }}$ rooms and one or two guns mounted on wheeled support in the $3^{\text {rd }}$ room to be conducted and placed outside through the ramp. The square pit (Tomezzoli, 2017) near the entrance was probably an open, drinking water cistern although the function of external observation post for the surveillance and protection of the bunker by one soldier cannot be ruled out. The absence of trace of a kitchen and latrines at the interior and a chimney at the exterior, indicate that the personnel lodged outside the bunker in disappeared barracks or tents and reached the bunker in case of alarms.

The bunkers (7), (27), (29)-(31), (39) correspond to casemates (Defensa, 2015).

The pillboxes and casemates of Lanzarote both for project and construction appear rather different with respect to the German Regelbauten (Rudi, 1998) and Italian bunkers (Tomezzoli, 2012, 2013, 2015b) and more similar to the British pillboxes type 22-28 (Pillbox Study Group, 2016-2018).

The old lighthouse was an excellent observation place for controlling the naval traffic in La Bocayna channel and in the open Atlantic Ocean. It was probably 
operated by a small garrison.

The geodetic stone (15), of recent construction (Tomezzoli, 2017), certainly was not an original component of the Lanzarote defences.

The satellite images confirm that Mirador del Rio hosted two artillery batteries (1)-(2) (Axis, 2012). The $1^{\text {st }}$ battery (1) comprised a command bunker (30), similar to the command bunker (7) of the artillery battery of Punta Limones, on the cliff edge for early discovery of objectives far in the ocean. The oval emplacement (28), retracted from the cliff edge probably hosted one or the two 77 mm guns (Axis, 2012). The rectangular bunkers (29), (31) hosted materials and personnel in service at the $1^{\text {st }}$ battery (1). The $2^{\text {nd }}$ artillery battery (2) apparently had no command bunker. Therefore, its fire was directed by the $1^{\text {st }}$ artillery battery (1) command bunker (30). The three circular artillery emplacements (32)-(34) and the oval artillery emplacement (37) hosted three of the four $210 \mathrm{~mm}$ howitzers (Axis, 2012). The buried bunker (39), the small construction (40) and the possible fort (42) hosted materials and personnel in service at the $2^{\text {nd }}$ battery (1). The trench (38) allowed protected access of the personnel from the buried bunker (39) to the gun in the oval emplacement (37). The closed area formed by the three sided barrier wall and the embankment (35) probably hosted disappeared barracks or tents for the personnel provided with drinking water through the open cistern (41).

\section{Conclusion}

Today, at about seventy years from the WWII end, to which they did not participated, the discovered Lanzarote military structures appear in good preservation state and, because of their location on the beaches, on the cliffs, and at Mirador del Rio, their integrity is not particularly menaced by possible further expansions of touristic and residential centres. In addition, their study provided examples of WWII Spanish military architecture and gave hints about the defence concepts involved in the WWII Lanzarote defence.

\section{Acknowledgements}

I thank very much Mr. L. Martinuzzi for having provided me with the article mentioning the presence of bunkers in Lanzarote and for having guided me to the discovery of said bunkers.

\section{Conflicts of Interest}

The author declares no conflicts of interest regarding the publication of this paper.

\section{References}

Anonym (2018). Churchill's Plan to Invade the Canaries. Gazette Life, February 2018, 19. Axis History Forum (2012). https://forum.axishistory.com/viewtopic.php?t=194258

Defensa de Canarias (2015). El Plan Pilgrim Foro El Gran Capitan. 
http://www.elgrancapitan.org/foro/viewtopic.php?p=765014

Pillbox Study Group (2016-2018). Types of Pillboxes. http://www.pillbox-study-group.org.uk/types-of-pillbox/

Rudi, R. (1998). Typologie du Mur de l’Atlantique. Beetsterwaag. NUGI 923.

Tomezzoli, G. (2012). Militärische Anlagen bei Verona. DAWA Nachrichten, Ausgabe 59, 4-27.

Tomezzoli, G. (2013). Der Bunker der Wehrmacht-Werkehrdirektion Italien in Verona. DAWA Nachrichten, Ausgabe 62, 4-13.

Tomezzoli, G. (2015a). The Ero Vili and the Atlantic Wall. Advances in Anthropology, 5, 183-204. https://doi.org/10.4236/aa.2015.54018

Tomezzoli, G. T. (2015b). A Small WWII Italian Bunker in Heraclea Minoa (Sicily). Advances in Anthropology, 5, 144-151. https://doi.org/10.4236/aa.2015.53013

Tomezzoli, G. T. (2017). The WW II German Stutzpunkt on the Menez-Hom (Finistere-FR). Archaeological Discovery, 5, 224-237. https://doi.org/10.4236/ad.2017.54013 